\title{
Interspecific differences in response to novel landmarks in bumblebees (Bombus sp.)
}

\author{
Dave Goulson*, Ben Darvill, Jon Ellis, Mairi E. KNIGHT, Mick E. HANLEY \\ Division of Biodiversity and Ecology, School of Biological Sciences, Biomedical Sciences Building, \\ Bassett Crescent East, Southampton SO16 7PX, UK
}

(Received 30 October 2003; revised 12 March 2004; accepted 19 March 2004)

\begin{abstract}
We provide evidence for interspecific differences in the behaviour of bumblebees which suggests that there may be important differences in the way that they navigate. Bumblebees commonly investigate the novel landmark presented by a human standing in open countryside. When doing so they perform a characteristic flight similar to that observed when a naïve bee first leaves the nest, suggesting that they are memorising the location of an unfamiliar landmark. We compare the frequency with which different bee species perform this behaviour. Striking patterns emerge. Only workers of certain bumblebee species were recorded investigating novel human landmarks, notably Bombus lapidarius and B. soroeensis. Other species such as B. pascuorum, B. hortorum and B. pratorum never performed this behaviour, yet were abundant in the study area. We suggest that this behaviour may be indicative of species with long foraging ranges and therefore greater need to pay attention to landmarks.
\end{abstract}

\section{Bombus / navigation / foraging range / memory}

\section{INTRODUCTION}

Despite much research, our understanding of the navigational abilities of animals remains far from complete. Honeybees (Apis mellifera L.) have received considerable attention in this respect; they can navigate up to $20 \mathrm{~km}$ from their nest in search of food, and are able to remember and communicate the locations of food sources (von Frisch, 1967; Seeley, 1985). They are known to rely heavily on visual landmarks (Southwick and Buchmann, 1995; Dyer, 1996), and also use a sun compass to relate the positions of landmarks and the nest (Wehner, 1994). They seem able to plot a direct trajectory home following a complex outward route, although exactly how they do this remains unclear. Some authors claim that bees develop "cognitive maps" of their landscape, although this remains controversial (Gould, 1986; Dyer, 1991; Menzel, 2001).

Some bumblebee (Bombus sp.) species can forage over several kilometres from their nests (Goulson and Stout, 2001; Osbourne et al., 2001; Walther-Hellwig and Frankl, 2000; Goulson, 2003), but the upper limits of their foraging range are not known. Marking experiments suggest that some species such as $B$. muscorum mostly remain within $200 \mathrm{~m}$ of their nests whilst others such as $B$. lapidarius and $B$. terrestris forage further afield (Walther-Hellwig and Frankl, 2000). Here we provide different evidence that there may be important differences in navigation behaviour between species.

\footnotetext{
* Corresponding author: DG3@ soton.ac.uk
} 
When standing in the countryside in summer it is common to be investigated by flying bumblebees, a phenomenon colloquially known as "buzzing" (for brevity this term is adopted here). The flying bee approaches to within 2$4 \mathrm{~m}$ of the person and then flies from side to side at a height of 2-4 m, describing a horizontal arc of increasing length. After perhaps $4 \mathrm{~s}$ the bee performs a series of two to five loops around the observer before flying away. This behaviour can be observed frequently, particularly when standing in open countryside with few obvious landmarks nearby.

Here we test whether bumblebees species differ in the frequency with which they perform this behaviour, by simultaneously comparing the numbers of different bumblebee species buzzing with the numbers observed in counts on flowers.

\section{METHODS}

Our study was carried out in July and August 2002 and 2003 on Salisbury Plain Military Training Area, UK. Salisbury Plain predominantly consists of large areas of undulating unimproved grassland, with few shrubs or trees and thus few natural landmarks. Forty six sites on the plain, each separated by at least $1 \mathrm{~km}$, were searched for one man hour. All sites lay between $51^{\circ} 06^{\prime}$ and $51^{\circ} 20^{\prime} \mathrm{N}$ and $1^{\circ} 40^{\prime}$ and $2^{\circ} 00^{\prime} \mathrm{W}$, and were between 150 and $200 \mathrm{~m}$ altitude. All bumblebees that were foraging on flowers were recorded. Bees that buzzed the researchers were netted and identified. It must be noted that catching these bees is difficult, and the success rate was probably less than $30 \%$. Any bee that flew from side to side, well above the vegetation, and while next to the observer, was deemed to be buzzing. Bees sometimes perform a similar behaviour when they are disturbed when foraging by an observer; where this was the case the bees were not classified as buzzing. The observers did not wear brightly-coloured clothing so the bees were unlikely to have mistaken the observer for an inflorescence, and bumblebees almost never spontaneously attack humans. Thus the buzzing behaviour was interpreted as being investigative. B. terrestris and B. lucorum where combined since these two species are exceedingly hard to distinguish reliably in the field. A $\chi^{2}$ test was used to examine whether the proportions of each bumblebee species recorded buzzing differed from the overall proportions of each species that were recorded at the study site. Rare species in which the expected number of bees recorded buzzing was less than five were pooled.

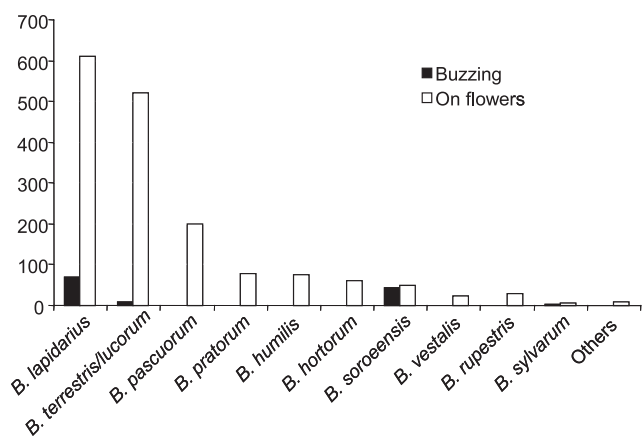

Figure 1. Numbers of each bumblebee species recorded on flowers versus buzzing, based on 46 one hour searches for bumblebees at sites scattered across Salisbury Plain, southern UK. All castes combined.

\section{RESULTS AND DISCUSSION}

One hundred and twenty three bumblebees were caught and identified while buzzing, while 1658 bumblebees were recorded foraging on flowers. In total 13 bumblebee species were recorded, but only four of these were ever recorded buzzing (B. lapidarius, B. soroeensis and small numbers of $B$. terrestris/lucorum and B. sylvarum) (Fig. 1). The proportions of each species recorded buzzing differed significantly between species $\left(\chi_{6}^{2}=269, P<0.001\right)$. All but six of the 123 bees caught buzzing were workers, the remainder being 3 male $B$. lapidarius and 3 male B. soroeensis. No cuckoo bumblebees (subgenus Psithyrus) were recorded buzzing. Species that were common but were never recorded buzzing include $B$. pascuorum, $B$. humilis, B. hortorum, B. pratorum, B. rupestris and $B$. vestalis. The incidence of buzzing does not follow taxonomic groupings. The four species which we recorded buzzing are all from separate subgenera of Bombus (Williams, 1998).

The present study suggests that there are important differences in the behaviour of bumblebees that we do not as yet understand. It seems probable that buzzing is related to navigation, and that buzzing bees are investigating new landmarks. The behaviour seems to be identical to that observed in naïve bees when they first emerge from the nest (D.G. unpublished data), which fly from side to side in an expanding arc while facing the nest entrance, 
presumably to memorise its position. Thus we hypothesize that buzzing bees are memorising the location of a novel landmark. We envisage that the behaviour occurs when a bee travelling through familiar territory encounters a new landmark, and pauses to add the position and shape of this landmark to its memory.

Why should some species "buzz" but not others? Even within those species recorded buzzing, some appear to do it much more frequently than others. Nearly half of the B. soroeensis recorded were buzzing (46\%), compared to just $10 \%$ for $B$. lapidarius. What is the significance of these inter-specific differences? Bumblebee species may differ in the range over which they forage. Walther-Hellwig and Frankl (2000) suggest that $B$. muscorum forage within $200 \mathrm{~m}$ of their nests whilst B. lapidarius and $B$. terrestris regularly forage over $>1 \mathrm{~km}$. Using molecular markers to identify sisters, we have recently found that $B$. terrestris workers tend to range over greater distances than those of B. pascuorum (Darvill et al., 2004). However, we do not have accurate estimates of mean or variance in foraging range for any bumblebee species. Presumably species that forage further afield pay more attention to landmarks. The species that we recorded buzzing broadly corresponds with those thought to have a large foraging range (particularly $B$. lapidar$i u s$ and $B$. terrestris), while B. pascuorum (which has a shorter foraging range) was never recorded buzzing. Little or nothing is known of the foraging range of the other species in our study, such as B. soroeensis. We know very little about the foraging range of most bumblebee species despite it being a fundamental aspect of their ecology. If there are big differences between species, this could affect their susceptibility to habitat change or degradation, and knowledge of foraging range would enable habitat management for rarer species on an appropriate scale. Clearly further research is needed in this area, particularly on the less well studied bumblebee species such as B. soroeensis.

Résumé-Différences interspécifiques en réponse à de nouveaux repères topographiques chez les bourdons (Bombus sp.). Il existe des preuves selon lesquelles les bourdons (Bombus sp.) peuvent présenter de grandes différences dans leur rayon de butinage, bien qu'il s'agisse d'un comportement notoirement difficile à quantifier. Nous apportons ici la preuve qu'il existe des différences interspécifiques nettes dans le comportement des ouvrières de bourdons. Cela suggère qu'il peut $y$ avoir des différences importantes dans la façon dont elles naviguent. Les bourdons examinent communément un nouveau repère topographique représenté par une personne debout au milieu d'un espace ouvert. Ce faisant, ils exécutent un vol caractéristique semblable à celui que l'on observe quand une abeille naïve quitte le nid pour la première fois, suggérant qu'ils mémorisent l'emplacement d'un repère non familier. Nous avons comparé la fréquence avec laquelle différentes espèces de bourdons présentaient ce comportement avec l'abondance globale de chaque espèce mesurée d'après des comptages sur les fleurs. L'étude a été menée dans la plaine de Salisbury, dans le sud de l'Angleterre, où existe une grande diversité d'espèces de bourdons. Les ouvrières de certaines espèces seulement ont été vues examiner les nouveaux repères humains, notamment Bombus lapidarius et $B$. soroensis, et occasionnellement $B$. terrestris/lucorum et $B$. sylvarum (Fig. 1). Les autres espèces comme $B$. pascuorum, $B$. hortorum et $B$. pratorum n'ont jamais présenté ce comportement, pourtant ils étaient présents en abondance sur le lieu d'étude. Nous suggérons que ce comportement peut être indicatif d'espèces ayant un long rayon de butinage et donc besoin d'une plus grande attention portée aux repères topographiques.

\section{Bombus / navigation / rayon de butinage / mémoire}

Zusammenfassung - Interspezifische Unterschiede bei der Reaktion auf neue Landmarken bei Hummeln (Bombus sp.). Es gibt viele Hinweise darauf, dass sich Hummelarten (Bombus Latr.) sehr stark in der Größe ihres Sammelareals unterscheiden, obwohl die Schwierigkeit einer Quantifizierung des Sammelverhaltens altbekannt ist. Hier zeigen wir Befunde, die auf einen deutlichen Unterschied im Verhalten der Hummelarbeiterinnen zwischen den Arten hinweisen. Sie deuten auf wichtige Unterschiede in der Methode ihrer Navigation hin. Allgemein erkunden Hummeln von Menschen aufgestellten neuen Landmarken in der offenen Landschaft. Dabei verfolgen sie eine typische Flugbahn ähnlich dem ersten Orientierungsflug von jungen Bienen, was zur Annahme führt, dass sie sich die unbekannten Landmarken einprägen. Wir verglichen die Frequenz dieses Verhaltens bei verschiedenen Hummelarten mit ihrer durch Zählungen an Blüten erfassten Vorkommenshäufigkeit. Die Untersuchung wurden in der Salisbury Ebene in Südengland durchgeführt, eine Gegend mit einer hohen Diversität an Hummelarten. Es ergaben sich erstaunliche Muster. Nur bestimmte Hummelarten wurden bei der Inspizierung der neuen für den Versuch errichteten Landmarken beobachtet, besonders häufig Bombus lapidarius und $B$. soroeensis, und manchmal B. terrestris/lucorum und B. sylvarum (Abb. 1). Andere Arten wie B. pascuorum, $B$. hortorum und $B$. pratorum zeigten niemals 
dieses Verhalten, obwohl sie in der Versuchsgegend häufig vorkamen. Wir vermuten, dass dieses Verhalten typisch für Arten mit einem großen Sammelgebiet ist, die aus diesem Grund genauer auf die Landmarken achten müssen.

\section{Bombus / Navigation / Sammelareal / Lernen}

\section{REFERENCES}

Darvill B., Knight M.E., Goulson D. (2004) Use of genetic markers to quantify bumblebee foraging range and nest density, Oikos 107, 471-478.

Dyer F.C. (1991) Bees acquire route-based memories but not cognitive maps in a familiar landscape, Anim. Behav. 41, 239-246.

Dyer F.C. (1996) Spatial memory and navigation by honeybees on the scale of the foraging range, J. Exp. Biol. 199, 147-154.

Frisch K. von (1967) The Dance Language and Orientation of Bees, Harvard University Press, Cambridge, Massachusetts.

Gould J.L. (1986) The locale map of honey bees: do insects have cognitive maps? Science 232, 861863.

Goulson D. (2003) Bumblebees; their behaviour and ecology, Oxford University Press, Oxford.
Goulson D., Stout J.C. (2001) Homing ability of the bumblebee, Bombus terrestris, Apidologie 32, 105-112.

Menzel R. (2001) Behavioral and neural mechanisms of learning and memory as determinants of flower constancy, in: Chittka L., Thomson J.D. (Eds.), Cognitive Ecology of Pollination, Cambridge University Press, Cambridge, pp. 21-40.

Osborne J.L., Clark S.J., Morris R.J., Williams I.H., Riley J.R., Smith A.D., Reynolds D.R., Edwards A.S. (1999) A landscape study of bumble bee foraging range and constancy, using harmonic radar, J. Appl. Ecol. 36, 519-533.

Seeley T.D. (1985) Honeybee Ecology, Princeton University Press, Princeton, NJ.

Southwick E.E., Buchmann S.L. (1995) Effects of horizon landmarks on homing success of honeybees, Am. Nat. 146, 748-764.

Walther-Hellwig K., Frankl R. (2000) Foraging distances of Bombus muscorum, Bombus lapidarius and Bombus terrestris (Hymenoptera, Apidae), J. Insect Behav. 13, 239-246.

Wehner R. (1994) The polarization-vision project: championing organismic biology, in: Schildberger K., Elsner N. (Eds.), Neural Basis of Behavioural Adaptation, G. Fischer, Stuttgart, New York, pp. 102-207.

Williams P.H. (1998) An annotated checklist of bumble bees with an analysis of patterns of description (Hymenoptera: Apidae, Bombini), Bull. Nat. Hist. Mus. London (Entomol.) 67, 79-152. 